\title{
Mineral Exploration in Glaciated Terrain Using Till Geochemistry
}

\section{by Ron N.W. DiLabio and William B. Coker}

Studies of the lithology and geochemistry of glacial till deposits have proved very useful in mineral exploration. Analysis of systematically collected samples can help to identify dispersal trains that can be traced up-ice to their source. This article reviews the background to drift prospecting and the many factors that must be taken into account in finding the source of both resistate minerals and trace elements found in glacial deposits. (Ed.)

\section{Introduction}

Mineral exploration in regions that were glaciated during the Quaternary period is hampered by the scarcity of outcrops, and by the variable thicknesses of glacial drift that mantle the bedrock. Several strategies have been designed to overcome the effects of glaciation, but those that have been successful in finding mineralization usually involve an understanding of the history of the glaciated landscape. Foremost among the exploration strategies are those that use the distinctive provenance features of till as an aid in exploration.

\section{Glacial Dispersal}

Till was produced during the Quaternary by the glacial erosion, transport, and deposition of fresh and weathered unconsolidated sediments and bedrock. It is therefore a geologically young sediment, which at any given site is not an in situ weathering product but a lithological summation of source units up-ice from the site. Debris from each source unit is dispersed down-ice to produce a ribbon-shaped or flame-shaped dispersal train, a body of till that is enriched in debris from the source relative to the till surrounding the train.

Shilts (1976) has shown that a plot of the abundance of glacially dispersed debris against distance down-ice approximates a negative exponential curve (Fig. 1) in which

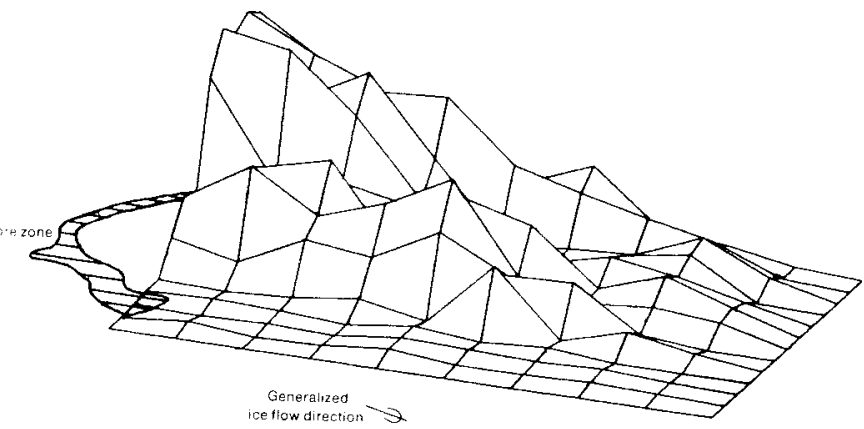

Figure 1: Perspective plot of the abundance of ore pebbles in till samples collected down-ice from an ore zone. Grid rectangles represent 30 by $60 \mathrm{~m}$. The highest peak reoresents $99 \%$. After DiLabio, 1981 . the concentration of a component reaches a peak (the "head") near its source and then declines exponentially (the "tail") to background levels down-ice. The size and shape of a dispersal train are controlled by the orientation of the source relative to ice flow, by the size and erodibility of the source, and by the topography of the source and dispersal areas, which can trap trains in valleys or break them into disjointed segments in rough terrain.

Distinctive components (e.g. gold, tungsten, tin, chromium, niobium, platinum) allow the identification of trains where such components are rare in the rocks of the dispersal area. Shilts (1973a, 1976) has shown, for example, that Cr-rich minerals derived from ultramafic rocks form distinet dispersal trains because bedrock in most dispersal areas is $\mathrm{Cr}$-poor. Similarly, trains of radioactive components can be mapped by airborne radiometric methods. Analytical sensitivity also enhances the distinctiveness of a component; for example, dispersal trains of gold have been identified in which the gold content of the heavy minerals in the till is only about $3 \mathrm{ppm}$ in contrast to much lower levels (as low as $50 \mathrm{ppb}$ ) outside the trains.

\section{Recycling of Sediment}

Till that is derived directly by erosion of bedrock is a firstcycle sediment (first derivative of bedrock, according to Shilts, 1976). Sediments resulting from reworking of till or other unconsolidated sediments are second-cycle sediments; they have been subjected to sorting and have undergone an episode of transport in water along a different path from the original. In this way, glaciofluvial gravel and sand represent the coarse fractions, and glaciolacustrine silt and clay the fine fractions of the till from which they were derived. Because these sediments have travelled along two distinct transport paths, first by ice then by water, it is more difficult to interpret their provenance than it is to trace till to its bedrock source (Shilts, 1973b).

\section{Sampling Designs and Types of Media}

Till samples used in mineral exploration surveys are usually collected along a linear or grid pattern at or near the surface to cover a specific area, such as, a map-area, a favourable geological environment or a specific structure. Receritly, increasing use has been made of samples collected stratigraphically, using drilling techniques to produce a three-dimensional data set.

Several different grain size fractions have been used routinely in the analyses of till. Surveys using till in the search for deposits containing resistate minerals (e.g., gold, scheelite, cassiterite, platinum) have used sand-sized heavy minerals for analysis. Unstable minerals such as sulphides are seldom recoverable in sand-sized heavy mineral concentrates collected at the surface, but they are routinely recovered where unweathered till samples have been collected from below the surface by drilling.

Experimental work (Shilts, 1984) has shown that the geochemically most active fraction of weathered till lies in its finer grain sizes because of the tendency for phyllosilicate minerals and secondary minerals to be enriched in the fine 
sizes. These phases have a high total surface area and exchange capacity, so they act as scavengers, adsorbing representative portions of the trace metals that are released during weathering of primary minerals, particularly sulphides. This pattern seems to hold for the base metals and uranium, for which the largest body of data is available (DiLabio, 1979; Shilts, 1984).

Similar fractionation experiments on gold-bearing till (Dilabio, 1982a, 1985) indicate that gold distributions in weathered till are rather complex, being the result of the combined effects of the grain sizes of glacially comminuted gold, the gold released from weathering sulphides, reprecipitated or adsorbed gold, and the gold at its source. In general, weathered till is richest in gold in its finer size ranges, although coarse sizes $(<2 \mathrm{~mm}$, rock fragments) are often auriferous (Fig. 2).

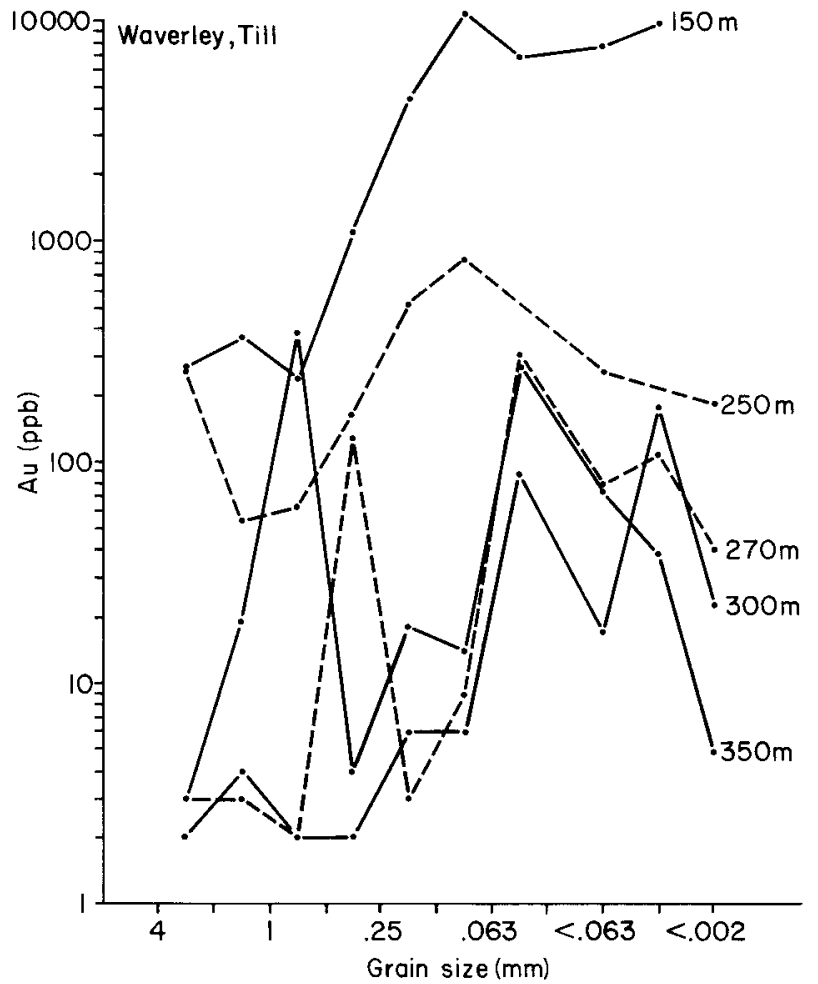

Figure 2 Abundance of gold vs. grain size of analyzed fraction of till at different distances down-ice from a gold deposit at waverley, Nova Scotia. After DiLabio, $1982 a$.

Although fractionation results have been collected to guide sampling and analytical programs using till, they have the additional value of showing the original distributions of trace elements before the till itself or the trace elements it contains are recycled into modern stream and lake sediments, sample media also commonly used in glaciated terrain.

Another influence on the geochemistry of till and its derivatives is their behaviour within the solum during postglacial time (Bolviken and Gleeson, 1979). Unlike in situ soils in unglaciated areas, those in glaciated terrain are geologically young, usually less than 10,000 years old, and their parent materials are immature allochthonous sediments derived from a variety of sources. Soils developed on till should, therefore, show a chemistry indicative of their original detrital lithology modified by the effects of trace element redistribution attributable to soil-forming processes. Within the soil profile, trace element abundances can vary widely across short depth intervals, and detailed orientation surveys are necessary to guide sample collection (DiLabio, 1982b; Shilts, 1984).

\section{Drift Prospecting}

Drift prospecting is defined here as the use of data on the geochemistry and lithology of glacial sediments (mainly till) to identify economically significant components in the sediments and to trace them to their bedrock source. Once a dispersal train has been detected, it can be traced relatively easily up-ice to its source, because simple clastic dispersal is the main process involved in the formation of a train.

Glacial dispersal trains exist at every scale up to hundreds of kilometres long. Trains of this latter size are detected only when the area sampled is very large and when the characteristic lithological component is present in adequate amounts and is distinctive against the background rock types in the dispersal area. For drift prospecting purposes, these large trains are significant in that the exotic lithology of the till can mask the lithology and geochemistry of mineralized debris eroded from local sources. Large trains such as these can be detected by "reconnaissance" scale till sampling, in which samples are collected at a density of one sample per $100 \mathrm{~km}^{2}$.

Smaller dispersal trains derived from individual rock units and distinctive belts of rock are more likely to be detected in the preliminary stages of mineral exploration programs. At this stage of exploration, "local" scale sampling, in which

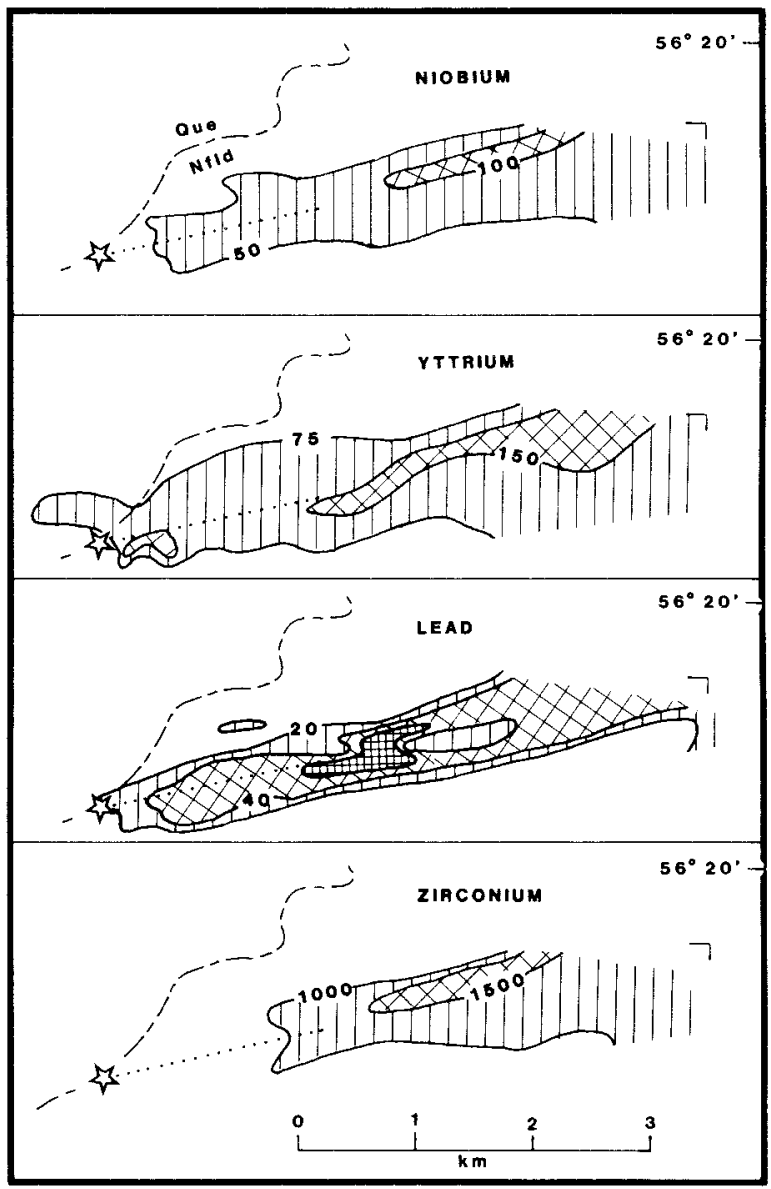

Figure 3: The niobium, yttrium, lead and zirconium contents ( $\mathrm{pm})$ of till in the strange Lake train, Quebec and Newfoundland. Star marks the subcrop of the mineralized zone. Dots mark the train of mineralized boulders. 
sample density is of the order of one per square kilometre, will suffice to define those parts of a favourable bedrock unit that are most metalliferous and may even detect the tails of dispersal trains derived from small mineralized sources.

"Detailed" sampling, in which sample density is of the order of one per hectare, is designed to locate the heads of dispersal trains. This is the density of sampling that would normally be earried out in drift prospecting programs tracing trains up-ice, testing geophysical anomalies or favourable geological contacts. Figure 3 illustrates some of the characteristic features of dispersal trains. They are ribbonor flame-shaped in outline; they have abrupt lateral edges with the surrounding barren till, and the values of the distinctive component within a train decay rapidly downice. At this scale of sampling, post-glacial mobilization of trace elements in groundwater may alter the original shape of the dispersal train, which is solely clastic in origin.

Most studies of dispersal trains for prospecting purposes have taken place in Fennoscandia and Canada, and the results of several studies are found in Kvalheim (1967), in the proceedings of conferences on prospecting in areas of glaciated terrain (e.g. IMM, 1986), and in Nichol and Bjorklund (1973), Bradshaw (1975), Minell (1978), and Kauranne (1976). Dispersal trains that have contributed to the discovery of ore deposits and prospects in Canada include the train of sphalerite-bearing boulders at George Lake, Saskatchewan (Karup-Moller and Brummer, 1970), the Icon trains, near Chibougamau, Quebec (DiLabio, 1981), the Hopetown, Ontario train (Sinclair, 1979; DiLabio et al., 1982), and the Strange Lake train (Fig. 3) of Labrador (Miller, 1986; Batterson et al., 1985).

Recent research has widened the scope of drift prospecting. Sampling of debris in transport and till in lateral moraines has proved useful in mineral exploration of areas of active alpine glaciation (DiLabio and Shilts, 1979; Stephens et al., 1983). The details of the mineralogy and weathering behaviour of metal-rich till are also being investigated (Nikkarinen et al., 1984; Peuraniemi, 1982).
One of the major unsolved problems in drift prospecting is the definition of the Quaternary stratigraphy and ice-flow history in areas of high mineral potential (Hirvas, 1977). Another is the relationship between the geochemistry of till and the sediments derived from it (Bergstrom et al., 1983). Topics such as these will be at the centre of research programs in Fennoseandia and Canada for the foreseeable future.

\section{(Geological Survey of Canada Contribution 44386)}

INQUA '87. Special Session 8: Mineral Exploration in Glaciated Terrain. Organizers: R.N.W. DiLabio (Canada) and w.B. Coker (Canada).

Dr. R.N.W. Dilabio has been a Research Scientist with the Geological Survey of Canada (601 Booth Street, Ottawa, Ontario, KlA 0E8) since 1976. He conducts research into mineral exploration methods for use in glaciated terrains, including boreal forest, tundra, and around contemporary glaciers, with emphasis on the geochemistry and lithology of till and derived sediments.

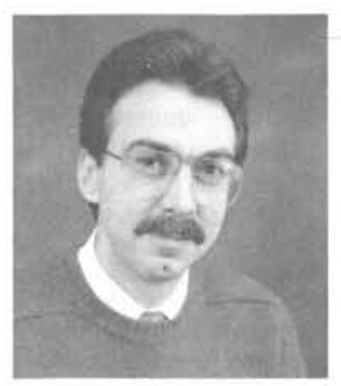

Dr. W.B. Coker has over 20 years experience with the mineral exploration industry and in government research. He is eurrently a Research Geochemist with the Geological Survey of Canada (601 Booth Street, Ottawa, Ontario, Canada K1A 0E8), condueting research primarily on overburden geochemistry in glaciated terrain.

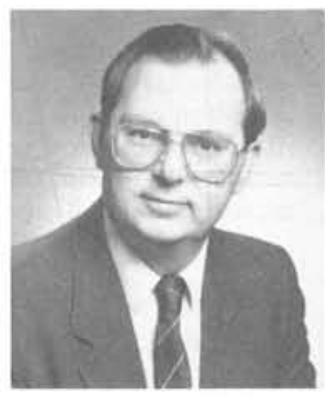

\section{References}

Batterson, M.J., Taylor, D.M. and Vatcher, S.V., 1985. Quaternary mapping and drif exploration in the Strange Lake area, Labrador. In: Current Kesearch, 1985. NewfoundIand Department of Mines and Energy, Mineral Levelopment Division, Report 85-1, p. $4-10$.

Bergstrom, J., Bjorklund, A., Bolviken, B., Lehmuspelto, P., Miagnusson, J., Ottesen, R.T. and Steenfelt, A., 1983. Geochemistry in the Nordkalott Project; (abst.). In: Abstracts of and Steenfelt, A., 1983. Geochemistry in the Nordkalott Project; (abst.). In: Abstracts of Finland, p. 6-7.

Bolviken, B. and Gleeson, C.F., 1979. Focus on the use of soils for geochemical exploration in glaeiated terrane. In: Hood, P.J., (ed.), Geophysies and Geochemistry in the Search for Metallic Ores. Geological Survey of Canada, Economic Geology Report 31, p. 295-326.

Bradshaw, P.M.L. (compiler and ed.), 1975. Conceptual models in exploration geochemistry - The Canadian Cordillera and Canadian Shield. Journal of Geochemical Exploration, v. 4, no. 1, p. 1-213.

DiLabio, R.N.W., 1979. Lrift prospecting in uranium and base-metal mineralization sites, District of Keewatin, Northwest Territories, Canada. In: Prospecting in areas of glaciated terrain 1979. Institution of Mining and Metallurgy, London, p. 91-100.

DiLabio, R.N.W., 1981. Glacial dispersal of rocks and minerals at the south end of Lac Mistassini, Quebec, with special reference to the leon dispersal train. Geological Survey of Canada, Bulletin 323, 46p.

DiLabio, R.N.W., 1982a. Gold and tungsten abundance vs. grain size in till at Waveriey, Nova Scotia. In: Current Research, Part B. Geological Survey of Canada, Paper 82-1B, p $57-62$.

DiLabio, R.N.W., 1982b. Drift prospeeting near gold oceurrences at Onaman River, Ontario and Oldham, Nova Scotia, In: Geology of Canadian Gold Deposits, Canadian Institute of Mining and Metallurgy, Special Volume 24, p. 261-266.

DiLabio, R.N.W., 1985. Gold abundance vs grain size in weathered and unweathered till. In: Current Research, Part A. Geological Survey of Canada, Paper 85-1A, p. 117-122.

DiLabio, R.N.W., Renez, A.N. and Egginton, P.A., 1982. Biogeochemieal expression of classic dispersal train of metalliferous till near Hopetown Ontario. Canadian Journal of Earth Seiences, v. 19, no. 12, p. 2297-2305.

DiLabio, R.N.W. and Shilts, W.W., 1979. Composition and dispersal of debris by modern glaciers, Bylot island, Canada. In: Schluchter, C. (ed.), Moraines and varves. Balkema, Rotterdam, p. 145-155.

Hirvas, H., 1977. Glacial transport in Finnish Lapland. In: Prospecting in areas of glaciated terrain. Institution of Mining and Metallurgy, London, p. 128-137.

IMM (Institution of Mining and Metallurgy), 1986. Prospecting in areas of glaciated terrain 1986. Institution of Mining and Metallurgy, London, 269p.
Karup-Moller, S. and Brummer, J.J., 1970. The George Lake zine deposit, Wollaston Lake area, northeastern Saskatehewan. Economic Geology, v. 65, no. 7, p. 862-874.

Kauranne, L.K., 1976. Conceptual models in exploration geochemistry, Norden, 1975. Journal of Geochemical Exploration, v. 5, no. 3, p. 173-420.

Kvalheim, A. (eo.), 1967. Geoehemical Prospecting in Fennoseandia. Interscience, New York, 350p.

Miller, R.R., 1986. Geology of the Strange Lake alkalic complex and the associated Zr-Y-Nb-Be-REE mineralization. In: Current Research, 1986, Newfoundland Department of Mines and Energy, Mineral Development Division, Keport 86-1, p. 11-19.

Minell, H., 1978. Glaciological interpretations of boulder trains for the purpose of prospecting in till. Sveriges Geologiska Undersokning, Serie C, v. 72 , no. $743,51 \mathrm{p}$.

Nichol, 1. and Bjorklund, A., 1973. Glacial geology as a key to geochemical exploration in areas of glacial overburden with particular reference to Canada. Journal of Geochemica Exploration, v. 2, no. 2, p. 133-170.

Nikkarinen, M., Kallio, E., Lestinen, P. and Ayras, M., 1984. Mode of oceurrence of Cu and $\mathrm{Zn}$ in till over three mineralized areas in Finland. Journal of Geochemical Exploration, v. 21, p. 239-247.

Peuraniemi, V., 1982. Geochemistry of till and mode of occurrence of metals in some moraine types in Finland. Geological Survey of Finland, Bulletin $322,75 \mathrm{p}$.

Shilts, W.W., 1973a. Glacial dispersal of rocks, minerals, and trace elements in Wisconsinan till, southeastern Quebec, Canada. In: Black, R.F., Goldthwait, R.P. and Willman, H.B. (eds.), The Wisconsinan Stage. Geological Society of Ameriea, Memoir 136, p. 189-219.

Shilts, W.W., 1973b. Drift prospecting; geochemistry of eskers and till in permanently frozen terrain: District of Keewatin, Northwest Territories. Geological Survey of Canada, Paper 72-45, 34p.

Shilts, W.W., 1976. Glacial till and mineral exploration. In: Legget, K.F. (ec.), Royal Society of Canada, Special Publication No. 12, p. 205-224.

Shilts, W.W., 1984. Till geochemistry in Finland and Canada. Journal of Geochemiea Exploration, v. 21 , no. $1-3$, p. $95-117$.

Sinciair, I.G.L., 1979. Geochemical investigation of the Clyde River zine prospect, Lanark Country, Ontario. In: Watterson, J.R. and Theobald, P.K. (eds.), Internationa Geochemical Exploration Symposium 1978. Association of Exploration Geochemists, p. $487-495$

Stephens, G.C., Evenson, E.B., Tripp, K.B. and Detra, D., 1983. Aetive alpine giaciers as a tool for bedrock mapping and mineral exploration: a case study from Trident Gilacier, Aleska, In: Evenson, E.B., Schluchter, C, and Kabasss, J. (eds), Tills and Belated Jeposits. Balkema, Rotterdam, p. 195-204. 